Article

\title{
Perspective on COVID-19 Pandemic Factors Impacting Organizational Leadership
}

\author{
James K. C. Chen * and Thitima Sriphon *(D) \\ Department of Business Administration, Asia University, Taichung 41354, Taiwan \\ * Correspondence: kcchen@asia.edu.tw (J.K.C.C.); sriphon@yahoo.com (T.S.)
}

check for updates

Citation: Chen, J.K.C.; Sriphon, T. Perspective on COVID-19 Pandemic Factors Impacting Organizational Leadership. Sustainability 2021, 13, 3230. https://doi.org/10.3390/ su13063230

Academic Editor: Grigorios

L. Kyriakopoulos

Received: 23 February 2021

Accepted: 10 March 2021

Published: 15 March 2021

Publisher's Note: MDPI stays neutral with regard to jurisdictional claims in published maps and institutional affiliations.

Copyright: (c) 2021 by the authors. Licensee MDPI, Basel, Switzerland. This article is an open access article distributed under the terms and conditions of the Creative Commons Attribution (CC BY) license (https:// creativecommons.org/licenses/by/ $4.0 /)$.

\begin{abstract}
Employees are important assets of an organization. Therefore, the employee engagement in teamwork is extremely vital for long-term organizational development. Good managers need excellent leadership skills. However, as the COVID-19 pandemic rapidly spreads around the world, many countries implemented strategies to avoid infection, such as working from home, isolation of infected people from others, and 14 days of self-quarantine. These strategies impact the trust, communal relationships, and social exchange relationships among organizational employees. However, communal and social exchange relationships are necessary for organizational leadership, and they are considered as the basis of social networks. The trust, communal relationships, social exchange relationships, and leadership in an organization are an interesting issue, particularly in the COVID-19 time, since the role of leaders is very crucial for maintaining organizational sustainability. The main objective of this study is to investigate the impact of COVID-19 on leadership in organizations based on trust, communal relationships, and social exchange relationships. The study employed correlation analysis to explore the interrelationships between variables. The 220 samples collected consisted of basic, middle, and high managers of organizations. The findings show that COVID-19 impacted organizational leadership. COVID-19 (F1) and (F2) factors integrated with each variable: (1) trust, (2) communal relationships, and (3) social exchange relationships created a stronger relationship between trust and leadership, communal relationships and leadership, and also social exchange relationship and leadership in organizations. On the contrary, Covid-19 (F3) factors integrated with each variable: (1) trust, (2) communal relationships, and (3) social exchange relationships decreased a relationship between trust and leadership, communal relationships and leadership, and also social exchange relationships and leadership in organizations. These results can help CEOs in organizations to perceive what factors have a positive impact or a negative impact on leadership in organizations in order to improve their leadership skills, even post COVID-19. The managerial implications are that (1) leaders need good communication skills to share true information with empathy and optimism and (2) leaders need to be thoughtful and capable to handle change in uncertain situations ethically.
\end{abstract}

Keywords: COVID-19; trust; communal relationships; social exchange relationships; organizational leadership

\section{Introduction}

Social sustainability is related to an employee's well-being and the relationship between employees and leaders in organizations [1]. In organizations, employees are treated as the most important assets [1,2]. Specially, leaders have the crucial task of making this asset sustainable in addition to protecting and maintaining their financial assets [2,3].

Since the COVID-19 pandemic has spread around the world. This pandemic has caused socio-economic responses not only as a health crisis but also affecting the life of society, the nation's safety, economic activities, and the change of work culture of organizations [4]. However, in the COVID-19 pandemic, leaders also have to confront unexpected changes in the social and economic crisis; to master those situations, leadership is required [5]. In such time of difficulty, leaders need to (1) make decisions quickly, e.g., 
to stop production or work remotely, (2) retain the mission and DNA of organizations, (3) collaborate with ecosystems, customers, and employees, as per Maslow's Hierarchy of Needs and people's basic necessities, (4) encounter the uncertainty of the situation personally while directing their team and organizations through it as leaders [5]. Hence, many policies resulting from the COVID-19 pandemic will directly affect leadership in organizations, since leaders are navigators of teams or organizations. For example, many countries enacted a work-at-home strategy, along with physical distancing, 14 days of self-quarantine, country border closing, and other methods considered to alleviate the spread of COVID-19 [4]. These policies have an impact on the trust and relationships among employees, which are required for organizational leadership as a basis of working social networks [6].

A lack of trust between managers and employees has occurred due to work from home because managers disagree with having employees work remotely [7]. Thereby, managers try to control and monitor employees more closely than they did before COVID-19, and this leads employees to feel uncomfortable and have negative feelings about their managers [7]. Commanding and controlling leadership without consultation or collaboration damages collaborative working and team relationships [8]. The trust deficiency leads to a negative outcome of organizational performance [8]. Consequently, the trust between each member in organizations can encourage a positive relationship that brings about the good performance of organizations.

Leaders encourage employee behavior in organizations through trust. When employees sense that they are trusted, they will likely have greater concern for their individual work [9]. Leadership character and actions lead to an employee's willingness to trust that leader $[10,11]$. However, the relationship between managers and employees aims toward sustaining trust, morale, and commitment in order to build a productive and secure work environment [12]. Moreover, employees' positive organizational relationships contribute toward the success of organizational goals and facilitating employee effectiveness [13].

As workplace plays a central role in many individuals' lives with connecting and supporting by co-workers and leaders, therefore, a positive social relationship is required [14]. The two major types of relationship the communal relationships and social exchange relationships are involved in social relationships [15]. Authentic leadership has a positive association with employees' communal relationships, since a communal relationship shows care and concern with other welfare [13]. A social exchange relationship can encourage behavior that supports objectives of organizations, because a social exchange relationship has a positive association with job performance and organizational citizenship [16]. Similarly, the leader-member exchange relationship positively relates to workplace friendship, and the workplace friendship positively relates to the team-member exchange relationship [17]. Consequently, the workplace friendship relates to the team-member exchange relationship and mediates leader-member exchange/team-member exchange relationships [17]. Further, both relationships can influence people's attitude to support people through a mix of social motivation, intrinsic, and extrinsic [18].

The main objective of this study is to investigate the impact of COVID-19 factors on leadership in organizations based on trust, communal relationships, and social exchange relationships. The results of this research will show: (1) the relationship between trust and communal relationships, (2) the relationship between trust and social exchange relationships, (3) the association between trust and leadership in organizations before and after influenced by COVID-9 factors, (4) the association between communal relationships and leadership in organizations before and after influenced by COVID-19 factors, and (5) the association of social exchange relationships and leadership in organizations before and after influenced by COVID-19 factors. Correlation analysis is used as a tool for analysis. The results will benefit CEOs of organizations in the development of appropriate approaches to enhance leadership performance in the future. 


\section{Theoretical Background}

\subsection{Authentic Leadership}

Authentic leadership is identified as the transaction of leaderships, ethics, balances processes, and positive organization behavior that comprises an individual's experiences, e.g., the thoughts, emotions, needs, values, and beliefs relevant to understanding the true self [19]. Authentic leadership results in greater self-awareness and self-regulation on the part of leaders and colleagues, supporting self-development [19]. Authentic leaders can understand their own strengths and weaknesses and show their true self and feelings to their subordinates to support mutual trust in the workplace [20].

Many scholars also stated that authentic leadership has four attributes: self-awareness, relational transparency, internalized moral perspective, and balanced processing of information $[19,21,22]$. To develop self-awareness in leaders, multisource feedback from others (followers, peers, and supervisors) can help leaders understand themselves [23]. Authentic leaders positively influence followers and organizational outcomes; for example, leaders who have self-awareness will have more positive relationships with others and lead to the eudaemonic well-being of employees in organizations [23]. Walumbwa et al. [22] demonstrated that authentic leadership is leader behavior that promotes both positive psychological capacities and a positive ethical climate. Thus, authentic leader behavior has a positive impact on employees, as the behavior encourages employees to express their concerns regarding the work and organizations toward completing the organization's goals [9].

\subsection{COVID-19-Influenced Time}

The COVID-19 pandemic shows a seriously and immediately adaptive challenge for leaders. Leaders have to be responsible for their organizations by establishing trust, collaborating, and sharing leadership to increase the organization's ability to survive during the time of crisis [6]. For instance, when leaders make decisions regarding remote work environments to practice social distancing, a rapid response of leaders is vital for managing the crisis effectively, with clear communication for all stakeholders [6]. Moreover, authentic leadership requires empathy, compassion, and flexibility to manage employees who are stressed by uncertain situations, and leaders require both emotional intelligence and emotional stability to drive their organizations because organizational employees experience genuine difficulties in their daily life [24]. Based on workplace challenges, the Mckinsey company surveyed more than 800 US employees on various topics related to employee experiences during the COVID-19 pandemic. The results suggest that leaders must build trust and relationships by presenting actions oriented to empathy and full transparency, since employees need safety and personal security at work as a basic need [24]. Similarly, Fernandez and Shaw [6] also argued that relationships are crucial in a crisis; therefore, leaders need to be engaged in active listening without judgment, accepting advice and criticism, and having transparent communication with one another to build relationships and mutual trust. Therefore, leaders can increase their leadership by listening to their employees, investing in relationships, meeting the safety and security needs of employees, including psychological safety in a team atmosphere [25], and enhancing a culture that values individuality and social harmony [24].

According to the Argyle Public Relationships Index, based on a survey of 1590 Canadians during 27-30 March 2020, on the association between employers and employees during COVID-19 pandemic, employees who lost their job did not blame their employers and attempted to retain a healthy relationship with one another. Subordinates were satisfied with their bosses when bosses took care of the subordinates who worked in the organization, subordinates trusted their bosses, bosses were concerned about their subordinates, and bosses were committed to meeting the expectations of their subordinates [26].

COVID-19 negatively impacts society from an economic perspective, an emotional perspective, and an ethical perspective [27]. COVID-19 provides an opportunity for people to witness the leadership of organizational leaders, how their leaders handle the crisis, 
and this situation exhibits the kind of leaders who they trust and believe. Trust is the core of all values; for example, collaboration and partnership need trust in their process, and all relationships are based on trust [27]. Particularly during COVID-19 followers trust in leaders because of their actions more than their words [27]. A trusting relationship, social cohesion, and an individual's purpose influence employee performance [24]. In a crisis, consensus is able to achieve success within an organization when it is formed with both the leader and follower teams [28]. High emotional intensity in leaders can add to employee anxiety [29]. Communications skills and the top leadership skills play a vital role in helping leaders maximize trust and reduce stress [29].

\subsection{Trust}

Interpersonal trust is very important for organizations. It can empower people to believe in others. Therefore, interpersonal trust can be described as the confidence and willingness of an individual to believe the words, actions, and decisions of others. Scholars have indicated that trust was essential for the effectiveness of relationship management [30]. Trust is a key factor of success in the cooperation and collaboration between parties [31]. When a trust-based relationship method is adopted, trust will be an input of the work relationship as a key focus of project management [31]. Mishra and Mishra [32] demonstrated that a culture of trust was able to develop when leaders showed trustworthiness in terms of reliability, openness, ability, and benevolence, and fulfill institutional trustbuilding mechanisms. Thus, a culture of trust is linked to institutional mechanisms that enhance this interpersonal behavior [32]. The leaders establish their trustworthiness and trusting behavior, which increases their vulnerability, which is essential for stimulating their followers not only to trust them but also to trust one another [32]. Mcallister [33] stated that work relationships among managers require cognitive-based trust to develop into affective-based trust, because, since the interpersonal relationship between managers and peers determines their ability to achieve their task, people expect peer trustworthiness before investing in further relationships. To build trust, the effort to assist and sentiments of care and concern for one another are very important [33]. People have to believe that they can talk freely to peers and that there is a willingness to listen and respond beneficially and caringly. Both sides also require an emotional investment in the work relationship; for instance, if one can no longer work in the team, other team members feel a sense of loss [33].

Lis et al. [34] demonstrated that leadership was most strongly associated with interpersonal relationships among the groups of intra-organizational antecedents; for instance, employees were able to believe one another when the managers' ability to encourage and motivate others was the strongest associated variable, and this was dependent on top and middle managers treating their followers with respect and establishing a culture of trust in organizations. The managerial behavioral attributes affecting interpersonal relationships were empathy, treating others with respect and building trust, and creating a good working environment in the organization; likewise, the strongest association of middle manager behavior was the interpersonal relationships within the working team. This brings about relationships among team members in organizations [34]. Affective reactions are related to judgments of trustworthiness of the new leaders [35]. Consequently, it is essential for the new leaders to build a perception of their ability with the team members. The judgment is then able to influence the evaluation of trust in the new leaders [35].

\subsection{Communal Relationships}

A communal relationship is explained as a relationship between friends or family members; this relationship leads people to feel responsible for others' welfare, want to help them when they are in need without expectation of return, and have positive attitudes toward supporting one another [36,37]. A communal relationship does not establish a debt or an obligation between people for returning a comparable benefit although sometimes there is an exchange of benefits in a communal relationship $[38,39]$. Hence, a communal 
relationship is involved with intrinsic motivation [18]. It is essential for a long-term relationship [36]. Clack and Mills [39] argued that when a communal relationship is desired, a benefit following aid is declined attraction, and they also determined that people do not want a communal relationship with people they do not like. Therefore, a person can have both a communal relationship and social exchange relationship with the same person such as, businesses can hire friends as employees [18,37]. A social exchange relationship is able to develop into a communal relationship, for instance, when employers marry employees [18].

Communal strength is a person's degree of internal driving force (motivation) to react to a communal partner's needs [40]. There are different levels of responses to a partner's needs depending on who that partner is; for instance, parents consider their child's needs before a friend's needs [40]. In addition, a communal relationship can be explained as follows: (a) communal strength is based on how close the relationship is, (b) the love scale is a high score in the communal strength measure, (c) liking can influence the communal strength toward their partners, and (d) a sense of obligation or duty expands a level of communal relationships [40]. Communal motivation enhances healthy relationships between both members of a relationship and the prosocial behavior among actors [41].

\subsection{Social Exchange Relationships}

The relationship between employees and their organizations often demonstrates a social exchange relationship since social exchange relationships require a comparable benefit between a giver and a recipient [38]. For example, the salary system influences an employee's turnover rate; if the pay satisfaction is low, the turnover intention among employees will increase [42]. When employees receive strong support from supervisors, the turnover intention decrease [42]. In a social exchange relationship, there is an obligation when a person assists another party, i.e., there is an expectation of receiving a return in the future; in the meantime, a social exchange relationship is dependent on trust and the investment in the relationship [16]. Therefore, a level of social exchange relationship can predict employee behavior since this type of relationship is identified as the working relationships in organizations $[16,43]$.

Social exchange relationships have a significant association with social motivation [18]. Social exchange relationships are short-term relationships when they are compared to communal relationships [36]. On the other hand, trust is essential for social exchange relationship improvement [44]. Thus, cognitive-based trust is related to exchange partners who are trusted because of their dependability and competency, and affective-based trust is emotionally engaged within social exchange relationships where partners are trusted since they exhibit care and concern for one another [44]. The relationship may begin with a social exchange relationship, but it can develop into a communal relationship; both communal and social exchange relationships are related to social motivation [18,37].

The main purpose of this paper is to study the perspective of the impact of COVID-19 factors on leadership in organizations. The study examined the correlation between leadership in organizations and trust, communal relationships, and social exchange relationships, with COVID-19 and without COVID-19 factors. The COVID-19 factors were used as a moderating mechanism through which trust, communal relationships, and social exchange relationships were positively correlated with leadership in organizations. Trust is needed to encourage the processes of team performance $[45,46]$. Trust in leaders is highly significant to team performance [47,48]. Trust is associated with communal relationships [49], and trust is a factor for the successful collaboration and cooperation between people [31].

\section{Materials and Methods}

\subsection{Research Design and Sampling}

This research used correlation analysis to explore the relationships between leadership and trust, communal relationships, and social exchange relationships, in the COVID-19 pandemic with the following steps: First, exploratory factor analysis (EFA) was used to 
identify factors and construct a set of measured variables, as this method can identify the underlying relationship between the measured variables [50,51]. The Pearson correlation [52] was used to find interrelationships between leadership in organizations and trust, communal relationships, and social exchange relationships. For example, the correlations between trust with COVID-19 factors and leadership and between trust without COVID-19 factors and leadership in organizations were different and had an effect on organizations.

Correlation can be used to measure the strength of a relationship between two quantitative variables when a strong correlation is defined as two or more variables that have a strong correlation, whereas a weak correlation is defined as variables that are poorly associated. Regarding multiple correlation, this study aims to discover whether COVID-19 variables (moderators) can influence leadership in organizations.

The data collection through a convenient sampling method, a questionnaire was distributed to 320 managers by email during 25 July 2020-31 August 2020, but only 225 managers $(70.31 \%)$ replied back. Moreover, due to incomplete questionnaires, 220 respondents $(68.75 \%)$ could be used. According to literatures, 220 samples could be representative of this study (see references which use 200 samples [20,31,49]). In addition, $87.70 \%$ (193 managers) were from Thailand, and the $12.3 \%$ (27 managers) were from Vietnam, Indonesia, and Taiwan. The demographic profiles of 220 respondents showed that the respondents were managers who were working in different types of businesses. Table 1 indicates that, out of 220 respondents, there were 102 males (46.4\%) and 118 females (53.6\%). Most of the respondents were $36-40$ years old $(49,22.3 \%)$, and the following rankings were $41-45$ years old $(34,15.5 \%)$ and $30-35$ years old $(29,13.2 \%)$. Most of the respondents were basic managers $(97,44.1 \%)$, middle managers $(52,23.6 \%)$, and high managers $(71,32.3 \%)$. Respondents had spent 5 years $(53,24.1 \%)$, over 20 years $(50,22.7 \%), 6-10$ years and $11-15$ years $(49,22.3 \%)$, or 16-20 years $(19,8.6 \%)$ working for their company.

Regarding work experience as a manager, many respondents were less than 5 years experienced $(67,30.5 \%)$ or $5-10$ years experienced $(77,35 \%)$, for a total of $65.5 \%$ of the overall respondents. Respondents worked in the service industry (54.1\%), manufacturing /factories $(23.6 \%)$, wholesale $(10.9 \%)$, and retail businesses $(11.4 \%)$. The total number of employees in respondents' companies was fewer than 10 (39.1\%), 10-49 (38.2\%), 50-249 $(10.5 \%)$, or over $250(12.3 \%)$. The annual revenue of respondents' companies was, less than USD10 million (80.5\%).

Table 1. Demographic profile of the respondents.

\begin{tabular}{lll}
\hline \multicolumn{1}{c}{ Demographic Variable } & Frequencies & Sample Percentage \\
\hline Respondent Age & 17 & \\
Less than 30 years & 29 & 7.7 \\
30-35 years & 49 & 13.2 \\
36-40 years & 34 & 22.3 \\
41-45 years & 28 & 15.5 \\
46-50 years & 22 & 12.7 \\
51-55 years & 14 & 10 \\
56-60 years & 27 & 6.4 \\
0ver 60 & & 12.3 \\
\hline Respondent Gender & 102 & \\
Male & 118 & 46.4 \\
Female & & 53.6 \\
\hline Respondent Position & 97 & \\
Basic Manager & 52 & 44.1 \\
Middle Manager & 71 & 23.6 \\
High Manager & & 32.3 \\
\hline
\end{tabular}


Table 1. Cont.

\begin{tabular}{|c|c|c|}
\hline Demographic Variable & Frequencies & Sample Percentage \\
\hline \multicolumn{3}{|l|}{ Respondent Years of Experience in the } \\
\hline \multicolumn{3}{|l|}{ Company } \\
\hline 5 years & 53 & 24.1 \\
\hline $6-10$ years & 49 & 22.3 \\
\hline $11-15$ years & 49 & 22.3 \\
\hline 16-20 years & 19 & 8.6 \\
\hline Over 20 years & 50 & 22.7 \\
\hline \multicolumn{3}{|c|}{ Respondent Work Experience as a Manager } \\
\hline Less than 5 years & 67 & 30.5 \\
\hline $5-10$ years & 77 & 35 \\
\hline $11-15$ years & 29 & 13.2 \\
\hline $16-20$ years & 19 & 8.6 \\
\hline Over 20 years & 28 & 12.7 \\
\hline \multicolumn{3}{|l|}{ The type of Company } \\
\hline Manufacturing/Factory & 52 & 23.6 \\
\hline Wholesale Business & 24 & 10.9 \\
\hline Retail Business & 25 & 11.4 \\
\hline Service Business & 119 & 54.1 \\
\hline \multicolumn{3}{|l|}{$\begin{array}{l}\text { Number of Employees in Respondent } \\
\text { Company }\end{array}$} \\
\hline Fewer than 10 employees & 86 & 39.1 \\
\hline 10-49 employees & 84 & 38.2 \\
\hline 50-249 employees & 23 & 10.5 \\
\hline 250 employees or more than people & 27 & 12.3 \\
\hline \multicolumn{3}{|l|}{ Company Annual Revenue } \\
\hline Not over USD10 million & 177 & 80.5 \\
\hline USD10 million- USD1 billion & 38 & 17.3 \\
\hline Over USD 1 billion & 5 & 2.3 \\
\hline Total Respondents & 220 & 100 \\
\hline
\end{tabular}

\subsection{Measurement}

This research used 33 statements with a five-point scale ranking, from strongly disagree to strongly agree. The Cronbach's alpha was a high reliability level of 0.984 . The statement was developed from Walumbwa et al. [22], Mcallister [33], Clark et al. [36], Shore et al. [16], DoLan et al. [27], Argyle Public Relationships Index [26], Fernandez and Shaw [6], and Kaul et al. [53].

\subsection{Exploratory Factor Analysis (EFA)}

To model the interrelationships between 16 items of COVID-19 factors with fewer variables, a set of EFAs was performed in SPSS.

Factor Loading Analysis

As shown in Table 2, Factor 1, i.e., COVID-19 (F1) factors, includes eight items: LO (13)-LO (16), SER $(9,10,12)$, and CR (6). Factor 2, i.e., COVID-19 (F2) factors, includes six items: Trust (1)-Trust (4) and CR (5, 7). Factor 3, i.e., COVID-19 (F3) factors, includes two items: CR (8) and SER (11). These three components played moderating roles in the next step. 
Table 2. Factor loading analysis. Leadership in organizations (LO), social exchange relationships (SER), communal relationships (CR).

\begin{tabular}{lccc}
\hline & & Component & F3 \\
\cline { 2 - 4 } & F1 & F2 & \\
\hline Covid-19 LO (16) & 0.754 & & \\
Covid-19 SER (10) & 0.751 & & \\
Covid-19 LO (15) & 0.681 & & \\
Covid-19 LO (13) & 0.654 & & \\
Covid-19 SER (9) & 0.639 & & \\
Covid-19 SER (12) & 0.622 & & \\
Covid-19 LO (14) & 0.614 & 0.771 & \\
Covid-19 CR (6) & 0.514 & 0.747 & \\
Covid-19 Trust (4) & & 0.739 & \\
Covid-19 Trust (2) & & 0.737 & 0.831 \\
Covid-19 Trust (1) & & 0.625 & 0.770 \\
Covid-19 Trust (3) & & 0.567 & \\
Covid-19 CR (5) & & & \\
Covid-19 CR (7) & & & \\
Covid-19 CR (8) & & & \\
Covid-19 SER (11) & & & \\
\hline
\end{tabular}

\subsection{Research Model and Hypothesis}

Based on the reviewed literature, the research model of this study is developed as illustrated in Figure 1. The research model incorporates trust, communal relationships (CR), social exchange relationships, organizational leadership (LO; dependent variable), and COVID-19 (F1, F2, F3) factors as moderators for each independent variable: (1) trust, (2) communal relationships, and (3) social exchange relationships). The rational interrelationships among these variables are discussed this section.

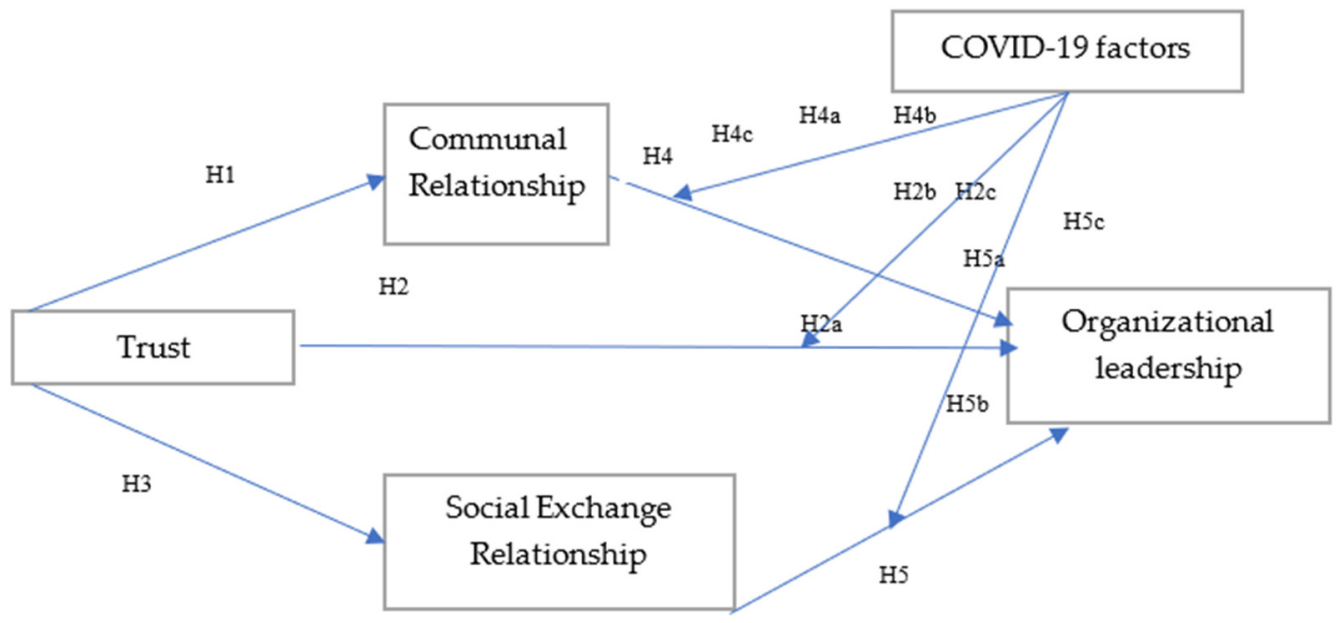

Figure 1. Research framework and hypothesis model.

\subsubsection{Trust and Communal Relationships}

There is a relationship between communal relationships and trust (both affective and cognitive based trust) [49]. Trust is the expectation that two parties can be counted on to engage in pro-relationship behaviors and be responsive to one's needs [54]. When people trust each other, they will invest their close relationships with increasing satisfaction [54]. To establish and maintain communal relationships is not easy [55]. An individual who is high in self-esteem and high in trust of others can be able to sustain communal relationships [55]. According to communal relationships, people feel good when they can help another party and they may feel bad when they cannot help [56]. Trust in partner predicts more positive 
behavior toward a partner over time, with a person who has more trust being more likely to be more helpful, and agreeable [57]. Therefore, trust is an important factor to help shaping behavior in close relationships [58]. People always trust individuals who have a strong communal relationship with them more than the ones who have a weak communal relationship with them [59]. Communal relationships are necessary for building and increasing trust in an organization, especially when the organizations need to add value to society, such as with social responsibility $[49,60]$.

Hypothesis 1 (H1). Trust has a significant and positive association with communal relationships.

\subsubsection{Trust and Leadership in Organizations}

Scholars stated that trust influences the performance of team processes $[45,46]$. Trust in leaders is an important factor that mediates leadership effectiveness [47]. Procedural justice can predict trust in supervisors and organizational citizenship behavior [61]. Consequently, authentic leadership fosters authentic relationships with followers and relates people by transparency, openness, and trust [21]. Most teams are directed by team leaders even when team members are self-managed; therefore, when team members rely on leaders, the leaders need to expand a certain degree of trust in them [62]. Trust in the leaders can predict team performance $[47,48]$. For instance, in a basketball team, trust in the coach was shown to significantly affect team performance (winning percentage) [47]. Both intra-team trust and team trust in leaders uniquely influence team performance because they have different responsibilities that are connected with distinct forms of dependence, vulnerability, and risk for team members [62]. Team members' trust in leaders determines the overall direction and collaboration of the team and controls the team's performance (e.g., negotiation, information, team work support, and being the team representative to bring the team to a higher organizational authority) [62]. Effective team performance requires both competencies and reliability on behalf of team leaders and members to achieve their responsibilities.

The succession event shows the vital role of trust in leaders; consequently, affective reactions have an association with the leader's trustworthiness [35]. Thus, authentic leadership behaviors can stimulate trust in the leader from subordinates leading to quality service for customers [63]. Authentic leadership has a positive impact on trust in workplaces, e.g., the trust in organizations, managers, and co-workers [64]. Stander et al. [65] indicated that authentic leadership brought about a positive outcome and an increasing level of trust among employees in organizations. Therefore, leaders cannot encourage work engagement unless there is employee trust in the organization [65].

In the current situation of COVID-19, the relationship between trust and leadership in organizations needs to be explored.

Hypothesis 2 (H2). Trust has a significant and positive association with leadership in organizations.

Hypothesis 2a (H2a). COVID-19 (F1) factors integrated with trust have a significant and positive association with leadership in organizations.

Hypothesis $\mathbf{2 b}$ (H2b). COVID-19 (F2) factors integrated with trust have a significant and positive association with leadership in organizations.

Hypothesis 2c (H2c). COVID-19 (F3) factors integrated with trust have a significant and positive association with leadership in organizations.

\subsubsection{Trust and Social Exchange Relationships}

Trust is very important for collaborations between people due to the fact that people have to rely on others to reach the organizational and individual goals. Mayer et al. [66] indicated that the nature of trust is cooperation, confidence, and predictability. Trust is an 
important success factor of organizations $[67,68]$. According to exchange theory, if leaders want to build a relationship with no reciprocal obligation, they need to reduce control and encourage trust; therefore, trust is an initial step to building relationships [69]. Social exchange relationships were discovered to be associated with trust initiation, as social exchange relationships are based on mutual trust toward one another, and trust is a basis of a relationship [69].

In addition, the social exchange relationships are concentrated on feeling obligation and trust [70]. Bernerth and Walker [70] suggested that trust influences the social exchange relationships between managers and employees; for instance, if managers and employees have more trust, employees tend to perceive a greater social exchange relationship. Likewise, the social exchange relationships are decreased when managers and employees have less trust [70]. Additionally, Massey et al. [44] indicated that trust is the influential variable mediating the effectiveness of social exchange relationships.

Hypothesis 3 (H3). Trust has a significant and positive association with social exchange relationships.

\subsubsection{Communal Relationships and Leadership in Organizations}

When followers perceive leaders' behavior as constituting examples of authentic leadership, they will pay more attention to their work; as a result, they will accomplish their organizational goals; furthermore, it is revealed that authentic leadership is positively associated with communal relationships [49]. Employers have to build communal relationships with their employees in order to develop the relationships in organizations; such type of relationships can influence employees to focus on their company's success without the desire of returns [15]. When authentic leadership is moderated with procedural justice, communal relationships are encouraged [13]. Moreover, the gender of leaders has an impact on leadership aspirations when communal orientation becomes a mediator and organizational identification is a moderator [71]. Female leaders present higher leadership aspiration than male leaders due to women's greater communal orientation [71]. In the COVID-19 pandemic, we propose that communal relationships and leadership in organizations may have empowered each other.

Hypothesis 4 (H4). Communal relationships have a significant and positive correlation with leadership in organizations.

Hypothesis 4a (H4a). COVID-19 (F1) factors integrated with communal relationships have a significant and positive correlation with leadership in organizations.

Hypothesis $\mathbf{4 b} \mathbf{( H 4 b )}$. COVID-19 (F2) factors integrated with communal relationships have a significant and positive correlation with leadership in organizations.

Hypothesis 4c (H4c). COVID-19 (F3) factors integrated with communal relationships have a significant and positive correlation with leadership in organizations.

\subsubsection{Social Exchange Relationships and Leadership in Organizations}

When a social exchange relationship is enhanced by a new leader's behavior, the intention of the team members to engage in the relationship produces the outcome: employees on the team will recognize new leaders that show efforts leading to a high-quality social exchange relationship and their leadership [35]. Corporate social responsibility positively mediates the relationship between authentic leadership and employees' organizational citizenship behaviors (OCB); in addition, authentic leadership, OCB, and corporate social responsibility are associated with one another [72].

According to social exchange theory, when workers are treated badly, a positive social exchange relationship is difficult to develop in organizations [73]. The relationship between leaders and subordinates affects the job satisfaction of employees, the productivity 
of work, information sharing, and employee turnover [74]. Likewise, researchers have stated that social exchange relationships can lead a person to support the goals of the organization and can increase the performances of employees [70]. Employees will display their willingness to work based on their quality of social exchange relationship with their leaders; as a result, employees' actions depend on the benefits they receive from leaders [38]. Consequently, leadership in organizations has a direct effect on social exchange relationships in organization [73]. Those who are in the role of effective leaders should measure the quality of the relationships between themselves and their employees by using the leader-member exchange relationship-7 system, which provides seven questionnaires regarding the relationship between leaders and followers and then uses these seven items to find the keys that drive relationship-building [74].

With the COVID-19 pandemic, we propose that the relationship between social exchange relationships and leadership in organizations is correlated with each other.

Hypothesis 5 (H5). Social exchange relationships have a significant and positive relationship with leadership in organizations.

Hypothesis 5a (H5a). COVID-19 (F1) factors integrated with social exchange relationships have a significant and positive relationship with leadership in organizations.

Hypothesis 5b (H5b). COVID-19 (F2) factors integrated with social exchange relationships have a significant and positive relationship with leadership in organizations.

Hypothesis 5c (H5c). COVID-19 (F3) factors integrated with social exchange relationships have a significant and positive relationship with leadership in organizations.

\section{Results}

\subsection{Data Analysis}

To investigate the relationship between leadership in organizations and trust, communal relationships, social exchange relationships, during COVID-19 pandemic, the Pearson correlation was used for exploring the interrelation between parties. In this study, COVID-19 (F1) factors, COVID-19 (F2) factors, and COVID-19 (F3) factors were moderating variables integrated with other independent variables to discover the level of relationships between leadership in organizations and trust, communal relationships, and social exchange relationships, during COVID-19 pandemic. COVID-19 (F1 F3) factors integrated with trust were COVID-19 (F1)_trust, COVID-19 (F2)_trust, and COVID-19 (F3)_trust, respectively. COVID-19 (F1 F3) factors integrated with CR were COVID-19 (F1)_CR, COVID-19 (F2)_CR, and COVID-19 (F3)_CR, respectively. Likewise, COVID-19 (F1 F3) factors integrated with SER were COVID-19 (F1)_SER, COVID-19 (F2)_SER, and COVID-19 (F3)_SER, respectively. The mean and standard deviation of each variable shows on Table 3.

Table 3. The mean and standard deviation of variable.

\begin{tabular}{cccccc}
\hline Variable & Mean & Std. Deviation & Variable & Mean & Std. Deviation \\
\hline Trust & 3.7945 & 0.70689 & COVID-19 (F1)_CR & 3.7776 & 0.65790 \\
CR & 3.7625 & 0.73023 & COVID-19 (F2)_CR & 3.7498 & 0.69150 \\
SER & 3.8602 & 0.69082 & COVID-19 (F3)_CR & 3.6631 & 0.72409 \\
LO & 3.8011 & 0.76335 & COVID-19 (F1)_SER & 3.8264 & 0.63514 \\
COVID-19 (F1)_trust & 3.7936 & 0.64072 & COVID-19 (F2)_SER & 3.7987 & 0.65993 \\
COVID-19 (F2)_trust & 3.7658 & 0.65506 & COVID-19 (F3)_SER & 3.7119 & 0.69122 \\
COVID-19 (F3)_trust & 3.6791 & 0.71201 & & & \\
\hline
\end{tabular}




\subsection{Hypothesis Testing}

Table 4 shows the relationship between variables. The relationship between trust and communal relationships had a positive and very strong association $(\beta=0.726)$ with a significance level of $p<0.001$. The result shows that, when trust increased, communal relationships also increased. Hypothesis 1 was fully supported. The relationship between trust and leadership in organizations had a positive and very strong correlation $(\beta=0.715)$ with a significance level of $p<0.001$. The result shows that, increased trust can strengthen leadership in organizations. Hypothesis 2 was fully supported. Likewise, the relationship between COVID-19 (F1)_trust and leadership in organizations had a positive and very strong correlation $(\beta=0.782)$ with a significance level of $p<0.001$. The result shows that, when COVID-19 (F1)_trust increased, leadership in organizations also increased. Hypothesis 2a was fully supported. The relationship between COVID-19 (F2)_trust and leadership in organizations also had a positive and very high correlation $(\beta=0.810)$ with a significance level of $p<0.001$. The result indicates that, when COVID-19 (F2) increased, leadership in organizations increased as well. Hypothesis $2 \mathrm{~b}$ was also fully supported. The association between COVID-19 (F3)_trust and leadership in organizations was also positively and strongly correlated $(\beta=0.621)$ with a significance level of $p<0.001$. The result presented that, when COVID-19 (F3)_trust increased, leadership in organizations also increased. Hypothesis $2 \mathrm{c}$ was fully supported.

Table 4. The results of multiple correlation.

\begin{tabular}{|c|c|c|c|}
\hline Relationship of Variables & Beta Value & $p$-Value & Hypothesis Test \\
\hline trust $\leftrightarrow \mathrm{CR}$ & $0.726^{* * *}$ & $p<0.001$ & Accept H1 \\
\hline trust $\leftrightarrow$ SER & $0.616^{* * *}$ & $p<0.001$ & Accept H3 \\
\hline trust $\leftrightarrow \mathrm{LO}$ & $0.715^{* * *}$ & $p<0.001$ & Accept H2 \\
\hline COVID-19 (F1)_trust $\leftrightarrow$ LO & $0.782^{* * *}$ & $p<0.001$ & Accept H2a \\
\hline COVID-19 (F2)_trust $\leftrightarrow$ LO & $0.810 * * *$ & $p<0.001$ & Accept $\mathrm{H} 2 \mathrm{~b}$ \\
\hline COVID-19 (F3)_trust $\leftrightarrow$ LO & $0.621^{* * *}$ & $p<0.001$ & Accept H2c \\
\hline $\mathrm{CR} \leftrightarrow \mathrm{LO}$ & $0.739 * * *$ & $p<0.001$ & Accept H4 \\
\hline COVID-19(F1)_CR $\leftrightarrow$ LO & $0.788^{* * *}$ & $p<0.001$ & Accept H4a \\
\hline COVID-19 (F2)_CR $\leftrightarrow$ LO & $0.792 * * *$ & $p<0.001$ & Accept $\mathrm{H} 4 \mathrm{~b}$ \\
\hline COVID-19(F3)_CR $\leftrightarrow$ LO & $0.634^{* * *}$ & $p<0.001$ & Accept H4c \\
\hline $\mathrm{SER} \leftrightarrow \mathrm{LO}$ & $0.645^{* * *}$ & $p<0.001$ & Accept H5 \\
\hline COVID-19 (F1)_SER $\leftrightarrow$ LO & $0.742 * * *$ & $p<0.001$ & Accept H5a \\
\hline COVID-19 (F2)_SER $\leftrightarrow$ LO & $0.759 * * *$ & $p<0.001$ & Accept H5b \\
\hline COVID-19 (F3)_SER $\leftrightarrow$ LO & $0.597 * * *$ & $p<0.001$ & Accept $\mathrm{H} 5 \mathrm{c}$ \\
\hline
\end{tabular}

Trust was positively and strongly associated with social exchange relationships $(\beta=0.616)$ with a significance level of $p<0.001$. The result revealed that, when trust increased, social exchange relationships increased as well. Hypothesis 3 was fully supported.

The correlation between communal relationships and leadership in organizations was positive and very strong $(\beta=0.739)$ with a significance level of $p<0.001$. The result shows that, when communal relationships increased, leadership in organizations increased. Hypothesis 4 was fully supported. The relationship between Covid-19 (F1)_CR and leadership in organizations had a positive and very strong correlation $(\beta=0.788)$ with a significance level of $p<0.001$. The findings introduced that, when Covid-19 (F1)_CR increased, leadership in organizations also increased. Hypothesis 4a was fully supported. The association between COVID-19 (F2)_CR and leadership in organizations was positively and very strongly correlated $(\beta=0.792)$ with a significance level of $p<0.001$. The findings point out that, when COVID-19 (F2)_CR increased, leadership in organizations increased as well. Hypothesis $4 \mathrm{~b}$ was fully supported. The association between COVID-19 (F3)_CR and leadership in organizations was positively and strongly correlated $(\beta=0.634)$ with a significance level of $p<0.001$. The findings show that, when COVID-19 (F3)_CR increased, leadership in organizations also increased. Hypothesis $4 \mathrm{c}$ was fully supported. 
Likewise, the relationship between social exchange relationships and leadership in organizations had a positive and strong correlation $(\beta=0.645)$ with a statistical significance of $p<0.001$. The findings show that, when social exchange relationships increased, leadership in organizations increased. Hypothesis 5 was fully supported. The relationship between COVID-19 (F1)_ SER and leadership in organizations had a positive and very strong correlation $(\beta=0.742)$ with a statistical significance of $p<0.001$. The finding shows that, when COVID-19 (F1)_SER increased, leadership in organizations increased as well. Hypothesis 5a was fully supported. The relationship between COVID-19 (F2)_SER and leadership in organizations had a positive and very strong correlation $(\beta=0.759)$ with a statistical significance of $p<0.001$. The finding show that, when COVID-19 (F2)_SER increased, leadership in organizations increased. Hypothesis $5 \mathrm{~b}$ was fully supported. The relationship between COVID-19 (F3)_SER and leadership in organizations had a positive and strong correlation $(\beta=0.597)$ with a statistical significance of $p<0.001$. The findings show that, when COVID-19 (F3)_SER increased, leadership in organizations also increased. Hypothesis 5 c was fully supported.

Hypothesis 1-5 show that trust had relationships with communal relationships, social exchange relationships, and leadership in organizations. Communal relationships had relationships with trust and leadership in organizations. Social exchange relationships had relationships with trust and leadership in organizations. Finally, COVID-19 factors Hypotheses 2, 4, 5 (a, b, c) show that COVID-19 (F1, F2, F3) factors integrated with each variable: (1) trust, (2) communal relationships, (3) social exchange relationships had an association with leadership in organizations.

\subsection{Perspective the Results of Moderating Effect of Hypothesis Test}

The main objective of this study is to investigate the impact of COVID-19 on leadership in organizations based on trust, communal relationships, social exchange relationships through the current COVID-19 crisis as well as the results between the moderating effects of COVID-19 (F1), COVID-19 (F2), and COVID-19 (F3) integrated with other independent variables. The outcomes of this study supported all hypothesized relationships. The results show that COVID-19 (F1) and COVID-19 (F2) present a positive moderating effect that can strengthen the relationship between of two original variables. For example, trust $\leftrightarrow \mathrm{LO}$ ( $\beta=0.739)$ is changed to COVID-19 (F1)_trust $\leftrightarrow$ LO ( $\beta=0.788)$ and COVID-19 (F2)_trust $\leftrightarrow$ LO $(\beta=0.810)$. On the other hand, the COVID-19 (F3) shows a negative moderating effect that COVID-19 (F3) beta value is reduced ( $\beta=0.621$ ). The other testing models H4 $(\mathrm{a}, \mathrm{b}, \mathrm{c})$ and $\mathrm{H} 5(\mathrm{a}, \mathrm{b}, \mathrm{c})$ also have same outcome. The detail follows as Figure 2.

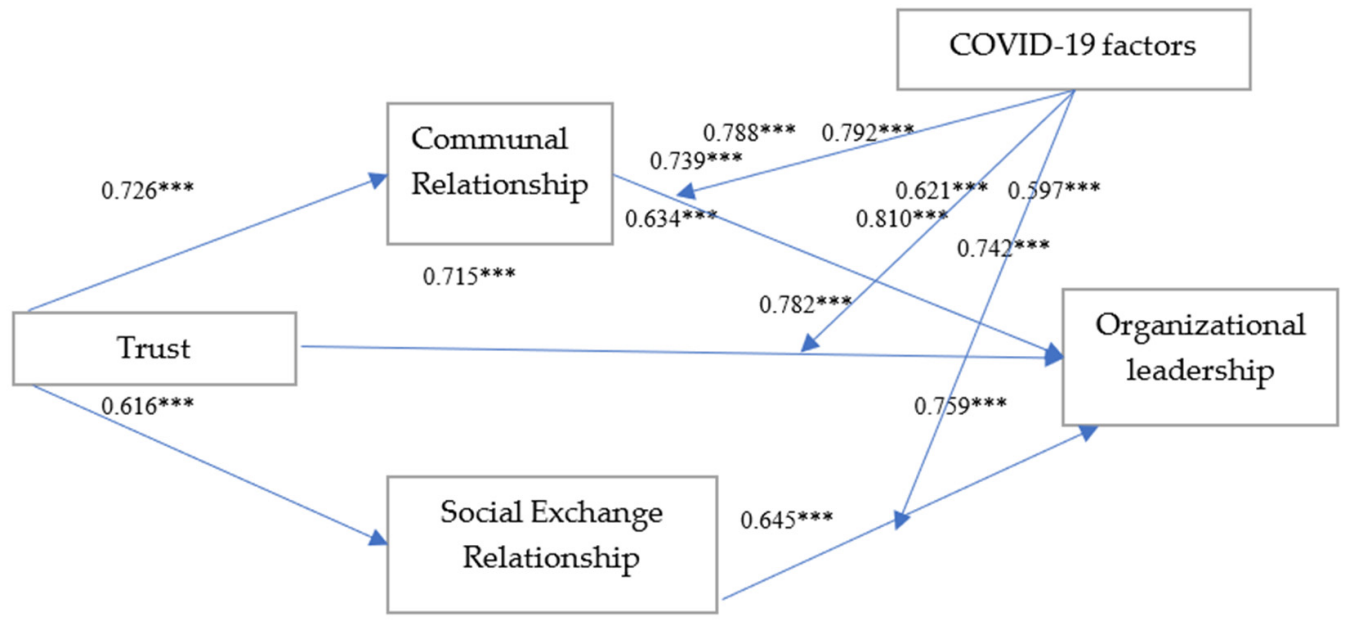

Figure 2. The results of moderating effect of test model. Notice: ${ }^{*}=<0.05,{ }^{* *}=<0.01,{ }^{* * *}=<0.001$, Correlation is significant at the 0.001 level; $\mathrm{N}=220$. 


\subsubsection{Hypotheses without COVID-19 Factors}

Hypothesis 1 reveals that trust has a positive correlation with communal relationships. Trust and communal relationships are essential for a team performance because employees require trust, stability, compassion, and expectation to reduce their stress from the risk of uncertainty both from their work and health $[31,60,75]$. Based on communal-sharing mental schemas, when the association between employees and leaders is based on a communal relationship, employees will pay more attention to the performance of their work and the company's reputation [76].

Hypothesis 2 reveals that trust has a positive correlation with organizational leaderships.

Trust binds everything that people do together: their relationships, their actions, and their expectations of others [77]. Thus, if employees trust in leaders, they will be motivated to perform their duty above expectations as well [77]. In addition, leadership can motivate organizational citizenship behavior through trust [64].

Hypothesis 3 reveals that trust has a positive correlation with social exchange relationships. Affective-based trust and cognitive-based trust are powerful variables for developing the effectiveness of social exchange relationships [44]. Moreover, both the manager and employee propensity to trust can influence the quality of a social exchange relationship [70].

Hypothesis 4 reveals that communal relationships have a positive correlation with organizational leadership. Iqbal et al. [13] indicated that authentic leadership influences employees' communal relationships and that procedural justice positively and significantly moderated the association between authentic leadership and employee communal relationships; therefore, the relationship between authentic leadership and communal relationships becomes positively strong when procedural justice is high. In consequence, communal relationships can influence leadership aspiration [71].

Hypothesis 5 reveals that social exchange relationships have a positive correlation with organizational leadership. Leadership can shape interpersonal relationships in organizations through leaders' attitudes and skills, leading to the quality of social capital, cooperation, and the commitment of employees [34]. However, affective attachment delivers a heightened tendency of related people to maintain social exchange relationships in organizations [78]. Thereby, a leadership intervention can increase the quality of social exchange relationships between leaders and team members, and this leads to increased productivity and job satisfaction [41].

\subsubsection{Hypotheses with COVID-19 Factors}

Hypothesis $(2 \mathrm{a}, 2 \mathrm{~b}, 2 \mathrm{c})$ reveals that COVID-19 (F1, F2, F3) factors integrated with trust have a positive association with organizational leadership. Encouraging shared leadership among team members and building culture of trust in organizations are required for managing virtual teams during COVID-19 [79]. Shared leadership in team members can improve team performance and collaboration because each team member needs to play a role in the collective leadership of team responsibility [79]. For sustaining culture of trust in organizations, managers need to take leadership actions to ensure they follow the commitments with employees, treat employees with fairness, transparency, and establish team trust [79]. Similarly, ethical leadership can influence employee engagement through organizational trust [80]. With the COVID-19 pandemic, employees require effective leaders who have the ability to inspire confidence, to collaborate on teamwork, and to focus on building trust with their employees; hence, employees feel safe and have confidence in their tasks to accomplish organizational goals [81]. In the same way, identification-based trust (IBT) (a type of trust based on the emotional connection between parties) has a positive linear relationship with the leader-member exchange relationship [82].

Hypothesis (4a, 4b, 4c) reveals that COVID-19 (F1, F2, F3) factors integrated with communal relationships have a positive association with organizational leadership. A communal relationship between employers and employees can emerge during COVID-19 
pandemic [26]. Communal orientations have a positive effect on leadership behaviors [83]. Therefore, employers or managers who show communal values will receive positive feedback from employees [83]. Employees and employers need this relationship to decrease stress arising from uncertain COVID-19 times [83]. When leader behavior is oriented to communal relationships, leaders will show care and concern to employees [75]. According to communal relationships, social contact supports the health and well-being of people when they hold the hands of the ones that they want (like); this indicates that healthy social relationships can reduce stress [84].

Hypothesis $(5 a, 5 b, 5 c)$ reveals that COVID-19 (F1, F2, F3) factors integrated with social exchange relationships have a positive association with organizational leadership. COVID19 pandemic has impacted the employers and employee's relationship [85]. Leadership is able to be considered as an activated process of social influence based on relationships [85]. Organizational leadership has connected with social exchange relationships related to power, dependence, value, trust, and commitment [86]. In family firms, affective attachment to the exchange triad and the balanced exchange triad can lead to a lower rate of the turnover of non-family CEOs [78]. Throughout the COVID-19 pandemic, building social exchange relationships and creating mutual trust requires leadership skills to engage in listening to employees without judgment, accepting employees' advice, communicating their perspectives transparently and frequently, and promoting their health [6]. Likewise, social exchange relationships are positively related to relationship satisfaction [87].

\section{Findings and Discussion}

\subsection{Discussion with COVID-19 Factors}

COVID-19 (F1) and (F2) increase the quality of leadership in organizations when they are integrated with (1) trust, (2) communal relationships, and (3) social exchange relationships. Thereby, COVID-19 factors have a strong impact on leadership in organizations. In brief, these factors suggest that the organizational leadership during COVID-19 pandemic needs to have trustworthiness/reliability, good communication skills, empathy, willingness to help organizational members, inspiring and motivating others, ability to handle change, and ethnics [see Appendix A]. The results show that, during the pandemic, the above factors have positively impacted leadership in organizations. Leaders have improved their leadership skills as evidenced by their actions, their communication, the well-being of their employees, their trustworthiness, their ability to handle change in uncertain situations, their moral or ethical behavior, their open-mindedness, and their empathy and support [6]. Moreover, psychological safety influences social exchange relationships between employees and organizations; as a result, employee performance improves [88,89]. Psychological empowerment affects the relationship between psychological safety and sustainable performance; thus, psychological empowerment has an impact on the association of sustainable leadership and sustainable performance through psychological safety when employees feel secure, they can deliver the best performance [90].

On the other hand, COVID-19 (F3) decreases the quality of leadership in organizations when it is integrated with (1) trust, (2) communal relationships, and (3) social exchange relationships. COVID-19 (F3) includes the following variable content: (1) remotely working staff interacted intimately with coworkers from their home online, and (2) leaders and staff increased interdependence online [see Appendix A]. This shows that remote work has interrupted the trust and relationships (both communal and social exchange relationships) between employees and managers during the pandemic since most managers feel uncomfortable with employees working at home because of a lack of trust and have tried to control and monitor employees closely than they were before COVID-19. As a result, some relationships between managers and employees have been damaged $[7,8]$. In consequence, teleworking reduces the organizational leadership of managers [85]. 


\subsection{Theoretical Implications}

Considering a theoretical perspective, the research model that is proposed in this study provides the foundation of leadership in organizations based on trust, communal relationships, social exchange relationships with COVID-19 pandemic and without COVID19 pandemic to understand the impact of COVID-19 factors to leadership of organizations. The study empirically indicated that the factors influence organizational leadership include trust, communal relationships, and social exchange relationships. Authentic leadership has focused on the relationship between leaders and followers that are identified by trust and integrity; also, authentic leadership has a positive influence on trust in leaders [63]. It contributes toward employee's trust in organizations and an influence of optimism on work engagement of employees [65]. Fair leadership can increase trust in leaders [77]. Additionally, trust in leadership can encourage team performance [47]. Thus, a key factor for building leadership is trust [77]. To create long-term relationship, leaders require leadership efforts to rise communal relationships in organizations [13]. Communal relationships are able to be encouraged by transparent, consistent, and truthful leadership; therefore, procedural justice can influence the association between employees' communal relationships and authentic leadership [13]. Likewise, authentic leadership concentrates on ethics and motivations employees to establish positive organizational environment [23]. Consequently, there is positive association between communal relationships and authentic leadership [49]. The positive relationship between employers and employees are based on the quality of social exchange relationships [73]. As social exchange relationships comprised both economic exchange and social motivation, working relationships in organizations are depended upon the ones [16]. Similarly, when non-family CEOs work in a family firm, the high quality of social exchange relationships between non-family CEOs and owner family is crucial for preventing CEOs turnover [78]. Consequently, an owner family needs the great leadership to protect employees to leave organizations [78].

Adopting COVID-19 factors as moderators can both increase and decrease leadership in organizations after being integrated with (1) trust, (2) communal relationships, and social exchange relationships. COVID-19 factors comprise fourteen items which are shown in Appendix A. The results show that COVID-19 factors regarding leaders' actions, their communication, employees' well-being, leaders' ethics, and leaders' emotional intelligence positively influence leadership in organizations. In time of COVID-19 pandemic, a rapid response from leadership and clear communication are necessary for an effective leader to manage crisis [6]. Moreover, the system of shared leadership between team members leads to increase a level of agility, innovation, and collaboration [6]. COVID-19 is the greatest threat in economy, emotions, and ethics [27]. In times of crisis, leaders will show care, companionship, and compassion as core value (leaders' emotional intelligence and employees "well-being") to unfold their leadership [27]. Additionally, core leadership principles during COVID-19 pandemic include communication, mission and core values, thinking outside the box, plan for the long and short term, engage with the ethics, and shared leadership [53]. On the other hand, COVID-19 factors of remote working or teleworking has reduced the relationship between managers and employees. Consequently, a lack of trust of mangers decreases organizational leadership [7,8]. Moreover, remote working causes social and professional isolation to adversely affect the performance of organizations [85].

\subsection{Managerial Implications of COVID-19 Case}

In this study the original data is collected from four countries that included Thailand, Vietnam, Indonesia, and Taiwan. The results can be used in worldwide organizations. The findings of this study are important to practitioners and managers. Under the pressure of COVID-19, it is essential for leaders to increase the trust and relationships of either communal relationships or social exchange relationships or both to enhance organizational leadership. In times like this, employees need leaders for guidance on what to do, what to expect, and how to action. During uncertain times, the need of strong, calm, and 
trustworthy leaders is more vital than ever. Thus, implications on practical level are introduced from this study:

First, communication skills help leaders to maximize trust and minimize stress and anxiety during uncertain times: managing stress, employees expect leaders to deliver their decisions and actions with calmness and deliberateness. Second, leaders should share information with empathy and optimism: in their communications, leaders should understand the uncertainty and anxiety employees are facing, especially when leaders have to communicate decisions that are likely to increase employee stress; for example, a reduction of work hours. Leaders should remember that employees who are anxious want their leaders to provide them with hope and a sense of control. A loss of control can bring about a sense of helplessness. Leaders should make employees feel that there is a good future and let employees realize how they can help other employees.

Third, leaders have to use credibility and trustworthiness to build trust: leaders receive credibility when they indicate that they comprehend the risks and situation. Leaders should be honest and transparent: to enhance trust and relationships, leaders should convey disappointing news clearly, straightforwardly, and truthfully. Leaders need to avoid giving wrong information that leads to misperceptions. Fourth, effective leaders will share all the facts quickly and not hide bad news. Leaders should provide regular communication: good leaders should have a communication routine so that employees can understand the real situation. As communication stops, employees are likely to imagine the worst. Leaders should provide a forum for feedback: employees will always have questions and will desire to give an appropriate advice. Leaders will receive trust when employees have an opportunity to get involved. Leaders are a role model: when employees do not know how they should behave, they take their leaders as a role model.

Fifth, leaders have to behave consistently with what they ask employees to do. Leaders are necessary to be the first to follow new policies, e.g., practicing social distancing and wearing masks. Employees practice after the leaders whom they trust and respect. In conclusion, leaders must communicate and share information with employees frequently and transparently to facilitate understanding. Emotional intelligence is needed to establish relationships between employers and employees. Leaders have to provide support in employees' health and safety.

Sixth, leaders need to perform three imperatives: (1) clarifying the purposes of organizations, (2) supporting organizational stakeholders, and (3) bolstering employees' emotional climate in organizations and the organizational resilience. For clarifying the purpose of organizations, leaders in a crisis should emphasize the organizational purposes to pull back and remind employees of their guiding principles. Emphasizing the purpose will make stakeholders have more confidence toward the organizations. Stakeholders are the people who drive and measure the leaders' success, and supporting organizational stakeholders can stimulate the trust, confidence, and morale required in organizations. In bolstering the emotional climate of employees in organizations and the organizational resilience, leaders need to prioritize their resolve in order to stay the course and to manage the attention that comes from the actions as well.

\section{Conclusions}

COVID-19 has increased the need to amplify our knowledge on how to build effective leadership in organization sustainability. Managers in times of crisis required a high level of leadership to navigate employees toward an organizational goal. However, there is a time when decentralization in a teamwork is needed, managers give an opportunity and power to team members (shared leadership) who have the ability to achieve the organizational tasks to encourage effective performance in a team and an organization. Then, trust and relationships (communal relationships and social exchange relationships) are essential for organizational leadership. Nevertheless, the new policies for COVID-19 prevention, such as social distancing and working from home have intervened on the trust and relationships between managers and employees. Remote-working environment has 
impacted organizational leadership [85]. Consequently, managers should find the ways to solve the problem such as, reducing the hours of working online and asking employees to return to the traditional workplace or sharing leadership in team members to make employees feel they are valuable to organizations.

This study can help leaders to improve their leadership skills for organization sustainability. It is important for managers to understand what factors affect leadership in organizations in order to adapt to the uncertainty of COVID-19 pandemic time. Therefore, managers can develop their leadership skills even post COVID-19.

\section{Limitations and Future Study}

As the COVID-19 pandemic is still in effect, it is difficult to collect data. This study used only 220 samples, which is a limitation on the number of respondents. We also used only correlation analysis to determine the relations between variables. In future research, more respondents and multiple linear regression will be used to find the influences and effects between variables.

Author Contributions: This paper ideas come from J.K.C.C.; J.K.C.C. and T.S. is same contribution on this paper. All authors have read and agreed to the published version of the manuscript.

Funding: This research was funded by Asia University R\&D office. The project No. "ASIA-107-AUH$04 "$. We are thankful for the Asia University R\&D department office fellowship and full support for this research.

Data Availability Statement: The original data presented in this study are available on request from the authors.

Acknowledgments: The authors thank the joiner who participated in this study, and who helped with observation and participant recruitment. The authors also thank the Institute of Innovation \& Circular Economy of Asia University, for Professor Tseng comments. Lastly, we appreciate the comments and feedback from the reviewers.

Conflicts of Interest: The authors declare no conflict of interest.

\section{Appendix A. COVID-19 Factors Details}

\begin{tabular}{|c|c|c|}
\hline COVID-19 (F1) Factors & COVID-19 (F2) Factors & COVID-19 (F3) Factors \\
\hline $\begin{array}{l}\text { (1) Leader were able to handle change efficiently } \\
\text { during the pandemic. (LO13) } \\
\text { (2) Leaders supported staff fairly (morally). (LO14) } \\
\text { (3) Leaders listened to staffs' opinions and } \\
\text { comments. (LO15) } \\
\text { (4) Leaders built the staffs' confidence through } \\
\text { empathy, support, and reassurance during the } \\
\text { pandemic. (LO16) } \\
\text { (5) Infected staff received more care from leaders. } \\
\text { (SER9) } \\
\text { (6) Leaders were able to meet expectations of staff, } \\
\text { so that staffs could remain productive and healty } \\
\text { during the pandemic. (SER10) } \\
\text { (7) Leaders boosted staffs' motivation by providing } \\
\text { support. (SER12) } \\
\text { (8) Leaders took care of staff in organizations } \\
\text { during the pandemic. (CR6) }\end{array}$ & $\begin{array}{l}\text { (1) Staff trusted leders more by their } \\
\text { actions than their words. (Trust1) } \\
\text { (2) Leaders had good and clear } \\
\text { communication with staff frequently } \\
\text { during COVID-19. (Trust2) } \\
\text { (3) Staff was able to rely on leaders } \\
\text { during the pandemic. (Trust3) } \\
\text { (4) Everyone believed that solidarity was } \\
\text { key toward true collaboration during the } \\
\text { pandemic. (Trust4) } \\
\text { (5) Staff followed the leaders like one } \\
\text { would follow a family leader during the } \\
\text { pandemic. (CR5) } \\
\text { (6) Leaders were concerned about their } \\
\text { staffs' well-being during the pandemic. } \\
\text { (CR7) }\end{array}$ & $\begin{array}{l}\text { (1) Remotely working staff } \\
\text { interacted intimately with } \\
\text { coworkers from their home } \\
\text { online. (CR8) } \\
\text { (2) Leaders and increased } \\
\text { interdependence by online } \\
\text { during the pandemic. (SER11) }\end{array}$ \\
\hline
\end{tabular}

\section{References}

1. Staniškienè, E.; Stankevičiūtè, Ž. Social sustainability measurement framework: The case of employee perspective in a CSRcommitted organisation. J. Clean. Prod. 2018, 188, 708-719. [CrossRef]

2. Pfeffer, J. Building Sustainable Organizations: The Human Factor. Acad. Manag. Perspect. 2010, 24, 34-45. [CrossRef] 
3. Guest, D.E. Human resource management and performance: Still searching for some answers. Hum. Resour. Manag. J. 2011, 21, 3-13. [CrossRef]

4. Global Data Coronavirus Executive Briefing-Business.att.com. n.d. Available online: https://www.business.att.com/content/ dam/attbusiness/briefs/att-globaldata-coronavirus-executive-briefing.pdf (accessed on 9 November 2020).

5. Deloitte, US. Leadership Beyond the Crisis. Available online: https://www2.deloitte.com/content/dam/Deloitte/de/ Documents/human-capital-consulting/COVID19_Leadership_Styles.pdf (accessed on 23 December 2020).

6. Fernandez, A.A.; Shaw, G.P. Academic Leadership in a Time of Crisis: The Coronavirus and COVID-19. J. Leadersh. Stud. 2020, 14, 39-45. [CrossRef]

7. KNOWLEDGE@WHARTON. What COVID-19 Teaches Us about the Importance of Trust at Work. Available online: https: / / knowledge.wharton.upenn.edu/article/covid-19-teaches-us-importance-trust-work (accessed on 23 December 2020).

8. Trimble, A. The Impact of Covid-19 on Working Relationships. Available online: https://www.kingsfund.org.uk/blog/2020/05/ impact-covid-19-working-relationships (accessed on 23 December 2020).

9. Hsieh, C.-C.; Wang, D.-S. Does supervisor-perceived authentic leadership influence employee work engagement through employee-perceived authentic leadership and employee trust? Int. J. Hum. Resour. Manag. 2015, 26, 2329-2348. [CrossRef]

10. Walumbwa, F.O.; Christensen, A.L.; Hailey, F. Authentic leadership and the knowledge economy. Organ. Dyn. 2011, 40, 110-118. [CrossRef]

11. Heyns, M.; Rothmann, S. Dimensionality of trust: An analysis of the relations between propensity, trustworthiness and trust. $S A$ J. Ind. Psychol. 2015, 41, 1-12. [CrossRef]

12. Bajaj, R.; Sinha, S.; Tiwari, V. Crucial Factors of Human Resource Management for Good Employee Relations: A Case Study. Int. J. Min. Metall. Mech. Eng. 2013, 1, 90-92.

13. Iqbal, S.; Farid, T.; Jianhong, M.; Mehmood, Q. Cultivating employees' communal relationship and organizational citizenship behavior through authentic leadership: Studying the influence of procedural justice. Psychol. Res. Behav. Manag. 2020, 11, 545-555. [CrossRef]

14. Houston, E. Importance of Positive Relationships in Workplace. Available online: https://positivepsychology.com/positiverelationships-workplace/ (accessed on 25 January 2021).

15. Hon, L.C.; Grunig, J.E. Guidelines for Measuring Relationships in Public Relations; The Institute for Public Relations, Commission on PR Measurement and Evaluation: Gainesville, FL, USA, 1999.

16. Shore, L.M.; Tetrick, L.E.; Lynch, P.; Barksdale, K. Social and economic exchange: Construct development and validation. J. Appl. Soc. Psychol. 2006, 36, 837-867. [CrossRef]

17. Tse, H.H.; Dasborough, M.T.; Ashkanasy, N.M. A multi-level analysis of team climate and interpersonal exchange relationships at work. Leadersh. Q. 2008, 19, 195-211. [CrossRef]

18. Johnson, J.W.; Grimm, P.E. Communal and exchange relationship perceptions as separate constructs and their role in motivations to donate. J. Consum. Psychol. 2010, 20, 282-294. [CrossRef]

19. Avolio, B.J.; Gardner, W.L. Authentic leadership development: Getting to the root of positive forms of leadership. Leadersh. Q. 2005, 16, 315-338. [CrossRef]

20. Wei, F.; Li, Y.; Zhang, Y.; Liu, S. The Interactive Effect of Authentic Leadership and Leader Competency on Followers' Job Performance: The Mediating Role of Work Engagement. J. Bus. Ethic 2016, 153, 763-773. [CrossRef]

21. Gardner, W.L.; Avolio, B.J.; Luthans, F.; May, D.R.; Walumbwa, F. “Can you see the real me?” A self-based model of authentic leader and follower development. Leadersh. Q. 2005, 16, 343-372. [CrossRef]

22. Walumbwa, F.O.; Avolio, B.J.; Gardner, W.L.; Wernsing, T.S.; Peterson, S.J. Authentic Leadership: Development and Validation of a Theory-Based Measure. J. Manag. 2008, 34, 89-126. [CrossRef]

23. Ilies, R.; Morgeson, F.P.; Nahrgang, J.D. Authentic leadership and eudaemonic well-being: Understanding leader-follower outcomes. Leadersh. Q. 2005, 16, 373-394. [CrossRef]

24. Emmett, J.; Schrah, G.; Schrimper, M.; Wood, A. COVID-19 and the Employee Experience: How Leaders Can Seize the Moment. Available online: https://www.mckinsey.com/business-functions/organization/our-insights/covid-19-and-the-employeeexperience-how-leaders-can-seize-the-moment (accessed on 9 November 2020).

25. Edmondson, A. Psychological Safety and Learning Behavior in Work Teams. Adm. Sci. Q. 1999, 44, 350. [CrossRef]

26. Relationships, A. Employer-Employee Relations Grow Stronger, even Amid COVID-19 Job Losses: Study. Available online: https:/ / www.newswire.ca/news-releases/employer-employee-relations-grow-stronger-even-amid-covid-19-job-lossesstudy-840741385.html (accessed on 9 November 2020).

27. Dolan, L.S.; Raich, M.; Garti, A.; Landau, A. The COVID-19 Crisis as an Opportunity for Introspection: A Multi-Level Reflection on Values, Needs, Trust and Leadership in the Future. Available online: https:/ / www.europeanbusinessreview.com/the-covid19-crisis-as-an-opportunity-for-introspection/ (accessed on 9 November 2020).

28. Carrington, D.J.; Combe, I.A.; Mumford, M.D. Cognitive shifts within leader and follower teams: Where consensus develops in mental models during an organizational crisis. Leadersh. Q. 2019, 30, 335-350. [CrossRef]

29. American Psychological Associaion. How Leaders Can Maximize Trust and Minimize Stress during the COVID-19 Pandemic. 2020. Available online: https://www.apa.org/news/apa/2020/03/covid-19-leadership.pdf (accessed on 9 November 2020).

30. Wong, E.S.; Then, D.; Skitmore, M. Antecedents of trust in intra-organizational relationships within three Singapore public sector construction project management agencies. Constr. Manag. Econ. 2000, 18, 797-806. [CrossRef] 
31. Meng, X. The role of trust in relationship development and performance improvement. J. Civ. Eng. Manag. 2015, 21, 845-853. [CrossRef]

32. Mishra, A.K.; Mishra, K.E. The research on trust in leadership: The need for context. J. Trust. Res. 2013, 3, 59-69. [CrossRef]

33. Mcallister, D.J. Affect- and cognition-based trust as foundations for interpersonal cooperation in organizations. Acad. Manag. J. 1995, 38, 24-59. [CrossRef]

34. Lis, A.; Glińska-Neweś, A.; Kalińska, M. The role of leadership in shaping interpersonal relationships in the context of positive organizational potential. J. Posit. Manag. 2015, 5, 28. [CrossRef]

35. Ballinger, G.A.; Schoorman, F.D.; Lehman, D.W. Will you trust your new boss? The role of affective reactions to leadership succession. Leadersh. Q. 2009, 20, 219-232. [CrossRef]

36. Clark, M.S.; Oullette, R.; Powell, M.C.; Milberg, S. Recipient's mood, relationship type, and helping. J. Pers. Soc. Psychol. 1987, 53, 94-103. [CrossRef] [PubMed]

37. Dunaetz, D.R. A Missionary's Relationship to Sending Churches: Communal and Exchange Dimensions. SSRN Electron. J. 2017. [CrossRef]

38. Clark, M.S.; Mils, J. The Difference between Communal and Exchange Relationships: What it is and is not. Pers. Soc. Psychol. Bull. 1993, 19, 684-691. [CrossRef]

39. Clark, M.S.; Mills, J. Interpersonal attraction in exchange and communal relationships. J. Pers. Soc. Psychol. 1979, 37, 12-24. [CrossRef]

40. Mills, J.; Clark, M.S.; Ford, T.E.; Johnson, M. Measurement of communal strength. Pers. Relatsh. 2004, 11, 213-230. [CrossRef]

41. Li, S.; Hui, C.-M. The Roles of Communal Motivation in Daily Prosocial Behaviors: A Dyadic Experience-Sampling Study. Soc. Psychol. Pers. Sci. 2019, 10, 1036-1045. [CrossRef]

42. Tnay, E.; Othman, A.E.A.; Siong, H.C.; Lim, S.L.O. The Influences of Job Satisfaction and Organizational Commitment on Turnover Intention. Procedia Soc. Behav. Sci. 2013, 97, 201-208. [CrossRef]

43. Johnson, D.; Grayson, K. Cognitive and affective trust in service relationships. J. Bus. Res. 2005, 58, 500-507. [CrossRef]

44. Massey, G.R.; Wang, P.Z.; Kyngdon, A.S. Conceptualizing and modeling interpersonal trust in exchange relationships: The effects of incomplete model specification. Ind. Mark. Manag. 2019, 76, 60-71. [CrossRef]

45. De Jong, B.A.; Elfring, T. How Does Trust Affect the Performance of Ongoing Teams? The Mediating Role of Reflexivity, Monitoring, and Effort. Acad. Manag. J. 2010, 53, 535-549. [CrossRef]

46. De Jong, B.A.; Dirks, K.T.; Gillespie, N. Trust and team performance: A meta-analysis of main effects, moderators, and covariates. J. Appl. Psychol. 2016, 101, 1134-1150. [CrossRef] [PubMed]

47. Dirks, K.T. Trust in leadership and team performance: Evidence from NCAA basketball. J. Appl. Psychol. 2000, 85, 1004-1012. [CrossRef]

48. Lau, E.; Rowlinson, S. Interpersonal trust and inter-firm trust in construction projects. Constr. Manag. Econ. 2009, 27, 539-554. [CrossRef]

49. Iqbal, S.; Farid, T.; Khan, M.K.; Zhang, Q.; Khattak, A.; Ma, J. Bridging the Gap between Authentic Leadership and Employees Communal Relationships through Trust. Int. J. Environ. Res. Public Health 2019, 17, 250. [CrossRef]

50. Norris, M.; Lecavalier, L. Evaluating the Use of Exploratory Factor Analysis in Developmental Disability Psychological Research. J. Autism Dev. Disord. 2010, 40, 8-20. [CrossRef]

51. Fabrigar, L.R.; Wegener, D.T.; Maccallum, R.C.; Strahan, E.J. Evaluating the use of exploratory factor analysis in psychological research. Psychol. Methods 1999, 4, 272-299. [CrossRef]

52. Stephanie, G. Correlation Coefficient: Simple Definition, Formula, Easy Calculation Steps. Available online: https://www. statisticshowto.com/probability-and-statistics/correlation-coefficient-formula/ (accessed on 10 November 2020).

53. Kaul, V.; Shah, V.H.; El-Serag, H. Leadership During Crisis: Lessons and Applications from the COVID-19 Pandemic. Gastroenterology 2020, 159, 809-812. [CrossRef] [PubMed]

54. Rusbult, C.E.; Wieselquist, J.; Foster, C.A.; Witcher, B.S. Commitment and Trust in Close Relationships an Interdependence Analysis. In Handbook of Interpersonal Commitment and Relationship Stability; Kluwer Academic/Plenum: New York, NY, USA, 1999; pp. 427-449.

55. Communal Relationships-IResearchNet. Available online: http://psychology.iresearchnet.com/social-psychology/ interpersonal-relationships / communal-relationships / (accessed on 27 January 2021).

56. Williamson, G.M.; Clark, M.S. The communal/exchange distinction and some implications for understanding justice in families Soc. Justice Res. 1989, 3, 77-103. [CrossRef]

57. Miller, P.J.E.; Rempel, J.K. Trust and Partner-Enhancing Attributions in Close Relationships. Pers. Soc. Psychol. Bull. 2004, 30, 695-705. [CrossRef] [PubMed]

58. Murray, S.L.; Holmes, J.G. Motivating Responsiveness: Five Elements to Relationship Know-How. In Interdependent Minds: The Dynamics of Close Relationships; Guilford Press: New York, NY, USA, 2011; pp. 11-17.

59. Rasmussen, K.R.; Alibhai, A.; Boon, S.D.; Ellard, J.H. Trust as an Explanation for Relational Differences in Revenge. Basic Appl. Soc. Psychol. 2016, 38, 284-300. [CrossRef]

60. Paine, K. Guidelines for Measuring Trust in Organizations (Updated). Available online: https://instituteforpr.org/guidelinesfor-measuring-trust-in-organizations-2/ (accessed on 10 November 2020).

61. Konovsky, M.A.; Pugh, S.D. CITIZENSHIP BEHAVIOR AND SOCIAL EXCHANGE. Acad. Manag. J. 1994, 37, 656-669. [CrossRef] 
62. Druskat, V.U.; Wheeler, J.V. Managing from the Boundary: The Effective Leadership of Self-managing Work Teams. Acad. Manag. J. 2003, 46, 435-457. [CrossRef]

63. Qiu, S.; Alizadeh, A.; Dooley, L.M.; Zhang, R. The effects of authentic leadership on trust in leaders, organizational citizenship behavior, and service quality in the Chinese hospitality industry. J. Hosp. Tour. Manag. 2019, 40, 77-87. [CrossRef]

64. Coxen, L.; Van Der Vaart, L.; Stander, M.W. Authentic leadership and organisational citizenship behaviour in the public health care sector: The role of workplace trust. SA J. Ind. Psychol. 2016, 42, 1-13. [CrossRef]

65. Stander, F.W.; De Beer, L.T.; Stander, M.W. Authentic leadership as a source of optimism, trust in the organisation and work engagement in the public health care sector. SA J. Hum. Resour. Manag. 2015, 13. [CrossRef]

66. Mayer, R.C.; Davis, J.H.; Schoorman, F.D. An Integrative Model of Organizational Trust. Acad. Manag. Rev. 1995, 20, 709. [CrossRef]

67. Colquitt, J.A.; Scott, B.A.; Lepine, J.A. Trust, trustworthiness, and trust propensity: A meta-analytic test of their unique relationships with risk taking and job performance. J. Appl. Psychol. 2007, 92, 909-927. [CrossRef] [PubMed]

68. Breuer, C.; Hüffmeier, J.; Hertel, G. Does trust matter more in virtual teams? A meta-analysis of trust and team effectiveness considering virtuality and documentation as moderators. J. Appl. Psychol. 2016, 101, 1151-1177. [CrossRef] [PubMed]

69. Whitener, E.M.; Brodt, S.E.; Korsgaard, M.A.; Werner, J.M. Managers as Initiators of Trust: An Exchange Relationship Framework for Understanding Managerial Trustworthy Behavior. Acad. Manag. Rev. 1998, 23, 513. [CrossRef]

70. Bernerth, J.B.; Walker, H.J. Propensity to Trust and the Impact on Social Exchange. J. Leadersh. Organ. Stud. 2008, 15, 217-226. [CrossRef]

71. Fritz, C.; Van Knippenberg, D. Gender and leadership aspiration: The impact of organizational identification. Leadersh. Organ. Dev. J. 2017, 38, 1018-1037. [CrossRef]

72. Iqbal, S.; Farid, T.; Jianhong, M.; Khattak, A.; Nurunnabi, M. The Impact of Authentic Leadership on Organizational Citizenship Behaviours and the Mediating Role of Corporate Social Responsibility in the Banking Sector of Pakistan. Sustain. J. Rec. 2018, 10, 2170. [CrossRef]

73. Cropanzano, R.; Anthony, E.L.; Daniels, S.R.; Hall, A.V. Social Exchange Theory: A Critical Review with Theoretical Remedies. Acad. Manag. Ann. 2017, 11, 479-516. [CrossRef]

74. Benge, M. Assessing the Relationship between Supervisors and Employees. EDIS 2019, 2019. [CrossRef]

75. Clark, M.S.; Armentano, A.L.; Boothby, E.J.; Hirsch, J.L. Communal relational context (or lack thereof) shapes emotional lives. Curr. Opin. Psychol. 2017, 17, 176-183. [CrossRef]

76. Fiske, A.P. The four elementary forms of sociality: Framework for a unified theory of social relations. Psychol. Rev. 1992, 99, 689-723. [CrossRef]

77. Sharkie, R. Trust in leadership is vital for employee performance. Manag. Res. News 2009, 32, 491-498. [CrossRef]

78. Waldkirch, M.; Nordqvist, M.; Melin, L. CEO turnover in family firms: How social exchange relationships influence whether a non-family CEO stays or leaves. Hum. Resour. Manag. Rev. 2018, 28, 56-67. [CrossRef]

79. Newman, S.A. Five Steps to Leading Your Team in the Virtual COVID-19 Workplace. Organ. Dyn. 2020, 100802. [CrossRef]

80. Ilyas, S.; Abid, G.; Ashfaq, F. Ethical leadership in sustainable organizations: The moderating role of general self-efficacy and the mediating role of organizational trust. Sustain. Prod. Consum. 2020, 22, 195-204. [CrossRef]

81. Hasel, M.C. A question of context: The influence of trust on leadership effectiveness during crisis. Management 2013, 16, 264-293. [CrossRef]

82. Scandura, T.A.; Pellegrini, E.K. Trust and Leader-Member Exchange. J. Leadersh. Organ. Stud. 2008, 15, 101-110. [CrossRef]

83. Thrasher, G.R.; Biermeier-Hanson, B.; Dickson, M.W. Getting Old at the Top: The Role of Agentic and Communal Orientations in the Relationship Between Age and Follower Perceptions of Leadership Behaviors and Outcomes. Work. Aging Retire. 2019, 6, 46-58. [CrossRef]

84. Coan, J.A.; Schaefer, H.S.; Davidson, R.J. Lending a Hand. Psychol. Sci. 2006, 17, 1032-1039. [CrossRef]

85. Contreras, F.; Baykal, E.; Abid, G. E-Leadership and Teleworking in Times of COVID-19 and Beyond: What We Know and Where do We Go. Front. Psychol. 2020, 11, 590271. [CrossRef]

86. Cortez, R.M.; Johnston, W.J. The Coronavirus crisis in B2B settings: Crisis uniqueness and managerial implications based on social exchange theory. Ind. Mark. Manag. 2020, 88, 125-135. [CrossRef]

87. Jeong, M.; Oh, H. Business-to-business social exchange relationship beyond trust and commitment. Int. J. Hosp. Manag. 2017, 65, 115-124. [CrossRef]

88. Newman, A.; Schwarz, G.; Cooper, B.; Sendjaya, S. How Servant Leadership Influences Organizational Citizenship Behavior: The Roles of LMX, Empowerment, and Proactive Personality. J. Bus. Ethic 2015, 145, 49-62. [CrossRef]

89. Newman, A.; Donohue, R.; Eva, N. Psychological safety: A systematic review of the literature. Hum. Resour. Manag. Rev. 2017, 27, 521-535. [CrossRef]

90. Iqbal, Q.; Ahmad, N.H.; Nasim, A.; Khan, S.A.R. A moderated-mediation analysis of psychological empowerment: Sustainable leadership and sustainable performance. J. Clean. Prod. 2020, 262, 121429. [CrossRef] 